INTER NATIONAL MONETARY FUND

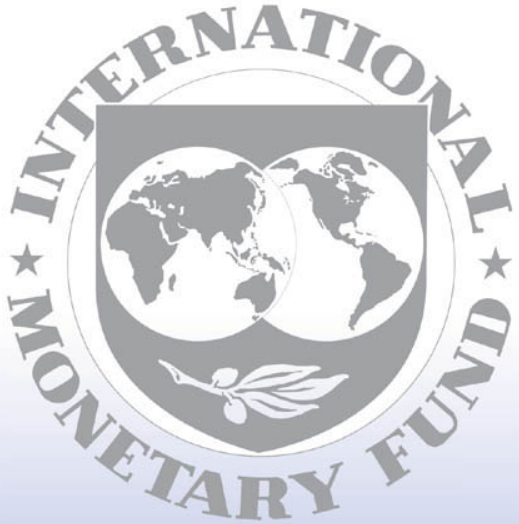

Staff

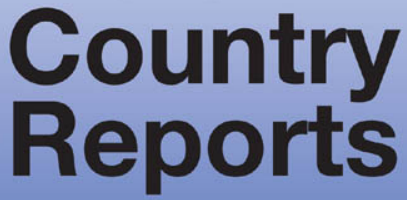




\section{Thailand: Financial Sector Assessment Program—Detailed Assessment of Observance of Thailand Securities Depository (TSD) of the CPSS/IOSCO Recommendations for Securities Settlement Systems}

This Detailed Assessment of Observance of Thailand Securities Depository (TSD) of the CPSS/IOSCO Recommendations for Securities Settlement Systems for Thailand was prepared by a staff team of the International Monetary Fund as background documentation to the Financial Sector Assessment Program with the member country. It is based on the information available at the time it was completed in April 2008. The views expressed in this document are those of the staff team and do not necessarily reflect the views of the government of Thailand or the Executive Board of the IMF.

The policy of publication of staff reports and other documents by the IMF allows for the deletion of market-sensitive information.

Copies of this report are available to the public from

International Monetary Fund $\bullet$ Publication Services 700 19th Street, N.W. • Washington, D.C. 20431

Telephone: (202) 623-7430 • Telefax: (202) 623-7201

E-mail: publications@imf.org • Internet: http://www.imf.org

\section{International Monetary Fund Washington, D.C.}


This page intentionally left blank

CInternational Monetary Fund. Not for Redistribution 
FinANCIAL SECtor Assessment PROGRAM

\section{THAILAND}

DETAILED ASSESSMENT OF OBSERVANCE

\section{THAILAND SECURITIES}

DEPOSITORY (TSD) OF THE

CPSS/IOSCO RECOMMENDATIONS

FOR SECURITIES SETTLEMENT

\section{SYSTEMS}

APRIL 2008

INTERNATIONAL MONETARY FUND

MONETARY AND CAPITAL MARKETS DEPARTMENT
THE WORLD BANK FinANCIAL AND PRIVATE SECTOR DEVELOPMENT VICE PRESIDENCY EAST ASIA AND PACIFIC REGION

VICE PRESIDENCY 
This page intentionally left blank

CInternational Monetary Fund. Not for Redistribution 


\section{Tables}

1. Detailed Assessment of Observance of Thailand Securities Depositories (TSD) of the Committee of Payment and Settlement Systems (CPSS)-International Organization of Securities Commission (IOSCO) Recommendations for Securities Settlement System (RSSS)s

2. Summary Observance of TSD of the CPSS-IOSCO Recommendations for Securities Settlement Systems

3. Recommended Action Plan to Improve Observance of TSD of the CPSS-IOSCO Recommendations for Securities Settlement Systems 


\section{GLOSSARY}

ATS

BOT

CCP

CPSS

CSD

DVP

FASB

GPF

IAS

ICAAT

IOSCO

MOC

MOU

OTC

RTGS

RSSS

SCB

SEA

SEC

SET

SWIFT

TSD
Automatic Transfer System for Securities Settlement

Bank of Thailand

Central Counterparty

Committee of Payment and Settlement Systems

Central Securities Depository

Delivery versus Payment

Financial Accounting Standards Board

Government Pension Fund

International Accounting Standards

Institute of Certified Accountants and Auditors of Thailand

International Organization of Securities Commission

Ministry of Commerce

Memorandum of Understanding

Over-the-Counter

Real Time Gross Settlement System

Recommendations for Securities Settlement System

Siam Commercial Bank

Securities and Exchange Act

Securities and Exchange Commission

Stock Exchange of Thailand

Society for Worldwide Interbank Financial Telecommunication Thailand Securities Depositories 


\section{Table 1. Detailed Assessment of Observance of Thailand Securities Depositories (TSD) of the Committee of Payment and Settlement Systems (CPSS)-International Organization of Securities Commission (IOSCO) Recommendations for Securities Settlement Systems (RSSS) ${ }^{1}$}

\begin{tabular}{|c|c|}
\hline Recommendation 1. & $\begin{array}{l}\text { Securities settlement systems should have a well-founded, clear and transparent legal } \\
\text { basis in the relevant jurisdiction. }\end{array}$ \\
\hline Description & $\begin{array}{l}\text { Accessibility of the regulatory framework } \\
\text { The laws, regulations, rules and procedures governing the operations and activities of } \\
\text { TSD are public and accessible to participants. In particular, participants receive } \\
\text { comprehensive documentation covering the rules, requirements, procedures and } \\
\text { instructions of TSD. This documentation is available on request and is accessible on } \\
\text { the TSD website. The public authorities' regulations are also available to the general } \\
\text { public on the websites of the Ministry of Commerce (MOC), the Securities and } \\
\text { Exchange Commission (SEC) and the Bank of Thailand (BOT). } \\
\text { Legal basis } \\
\text { The securities clearing and settlement activities in Thailand are governed and } \\
\text { regulated by specifically issued laws and regulations and by provisions in other } \\
\text { legislations and regulations. The main laws and regulations are: } \\
\text { - The Civil and Commercial Code: (e.g., provisions governing juristic acts, } \\
\text { obligations, contracts); } \\
\text { - The Securities and Exchange Act B.E. 2535 (SEA) (Sections 50-55,199, } \\
\text { 224-228); } \\
\text { - The Public Limited Company Act B.E. 2535; } \\
\text { - The notifications, rules, and regulations issued by the Stock Exchange of } \\
\text { Thailand (SET), and the TSD; } \\
\text { - The agreement between members and the TSD as a central securities depository } \\
\text { (CSD) and a clearinghouse; } \\
\text { - BAHTNET Rules and Regulations B.E. 2549; and } \\
\text { - The Bankruptcy Act B.E. } 2483 \text {. } \\
\text { obliged to separate between its securities holdings and customers' holdings. TSD is } \\
\text { also required to separate between its own securities holdings and the assets of its } \\
\text { (b) Customer assets protection } \\
\text { (a) Enforceability of transactions } \\
\text { The contractual arrangements between TSD and its participants are fully enforceable } \\
\text { with the TSD, which binds the participant to the TSD Regulations. TSD Regulations } \\
\text { can be enforced through a legal action. }\end{array}$ \\
\hline
\end{tabular}

\footnotetext{
${ }^{1}$ The main assessor was Elias Kazarian, Sernior Financial Sector Expert, IMF.
} 
participants.

In addition, entities acting as custodians such as banks, investment firms and other financial intermediaries are legally obliged to have an internal accounting system that allows the identification of the holdings of their customers at anytime.

\section{(c) Immobilization and dematerialization of securities}

In accordance with Sections 225-228 of the SEA, immobilization in the TSD system has been arranged through the transfer of securities by book entry. The transfer of securities by book entry shall be deemed to be the delivery of securities which constitutes the legal basis for the validity of securities transfer under Section 199 and Section 51 of the SEA. Moreover, securities transferred into the name of the TSD shall be presumed to be securities held by the TSD on behalf of its members or for any customers of its members.

However, there is no explicit legislation for the dematerialization of securities.

\section{(d) Netting arrangements}

TSD assumes the role of central counterparty (CCP) for multilateral netting procedure that takes place before the settlement is executed. This netting arrangement is enforceable under Sections 341-348 of the Civil and Commercial Code and Section 102 of the Bankruptcy Act B.E. 2483. However, since Section 102 of the Bankruptcy Act allows netting of obligations only if the cause of indebtedness incurred before the date of the receivership order, the TSD may not net its obligations against the obligations of the insolvent participant which arise on that date.

\section{(e) Securities lending arrangements}

Securities lending and collateralization arrangements are based on the outright transfer of securities. The SEC rule requires the transfer of the legal title in securities borrowed from the lender to the borrower, and the legal title in collateral is transferred from the borrower to the lender.

\section{(f) Finality of settlement}

TSD rule clearly states the timing of finality and the way finality is achieved. The transfer of funds is enforced by the BOT regulation.

Furthermore, there is no explicit legal protection for settlement finality. It can be challenged by a court decision. In accordance with Section 115 of the Bankruptcy Act, the court is empowered to reverse the debtor's transfer of assets during the three months prior to an application to adjudicate him as bankrupt and thereafter if the court finds that the debtor transfers such assets with the intention to give undue preference to a creditor. Thus, if the court orders receivership of a clearing house member or a settlement bank, the court may cancel the transfer of funds and securities made during that period if the official receiver is able to prove that the transfer has been made by the debtor with the intention to cause other creditors a disadvantage. 


\begin{tabular}{|c|c|}
\hline & $\begin{array}{l}\text { (g) Delivery versus payment (DVP) } \\
\text { TSD rule clearly states that all securities transactions must be settled on a DVP basis. } \\
\text { Challenges by a court } \\
\text { No court case has yet occurred. } \\
\text { Enforceability of rules and regulations in the event of a bankruptcy } \\
\text { There is no explicit legal protection of the netting procedures as well as the settlement } \\
\text { finality when insolvency is involved. Consequently, it cannot be ruled out that } \\
\text { transactions settled in TSD will be protected against a court decision in the event a } \\
\text { participant becomes insolvent. } \\
\text { Cross-border participation } \\
\text { There is no cross-border participation in TSD. } \\
\text { Conflict of law issues } \\
\text { Not applicable }\end{array}$ \\
\hline Assessment & Broadly observed \\
\hline Comments & $\begin{array}{l}\text { For the observance of this recommendation, it is recommended to implement } \\
\text { adequate legal measures that ensure the netting arrangement is legally protected even } \\
\text { in the event of the insolvency of a participant. }\end{array}$ \\
\hline Recommendation 2. & $\begin{array}{l}\text { Confirmation of trades between market participants should occur as soon as possible } \\
\text { after trade execution, but no later than trade date }(\mathrm{T}+0) \text {. Where confirmation of trades } \\
\text { by indirect market participants (such as institutional investors) is required, it should } \\
\text { occur as soon as possible after trade execution, preferably on } \mathrm{T}+0 \text {, but no later than } \\
\mathrm{T}+1 \text {. }\end{array}$ \\
\hline Description & $\begin{array}{l}\text { Direct participants } \\
\text { - Regulated markets (e.g., equities, government and private bonds) } \\
\text { For transactions traded on regulated markets, trade confirmation and matching is } \\
\text { required prior to the settlement. Trade confirmation between direct participants take } \\
\text { place on trade date. } \\
\text { - Over-the-counter (OTC) markets } \\
\text { For OTC transaction, } 90 \text { percent of trade is confirmed on T }+0 \text {. } \\
\text { Indirect participants } \\
\text { Trade confirmations between direct and indirect market participants are not } \\
\text { mandatory. However, for settlement of equities and bonds, trade confirmation } \\
\text { between direct and indirect participants takes place between T+0 and T+3. As a } \\
\text { general practice, direct participants will issue confirmation document within } \mathrm{T}+1 \text {. If } \\
\text { either of them does not confirm the settlement instructions, the TSD will settle such }\end{array}$ \\
\hline
\end{tabular}




\begin{tabular}{|c|c|}
\hline & $\begin{array}{l}\text { transactions through direct market participants directly. For settlement of bonds } \\
\text { traded via the trading system confirmation between direct and indirect participants } \\
\text { takes place between } \mathrm{T}+0 \text { and } \mathrm{T}+3 \text {. }\end{array}$ \\
\hline Assessment & Observed \\
\hline Comments & \\
\hline Recommendation 3. & $\begin{array}{l}\text { Rolling settlement should be adopted in all securities markets. Final settlement should } \\
\text { occur no later than } T+3 \text {. The benefits and costs of a settlement cycle shorter than } T+3 \\
\text { should be assessed. }\end{array}$ \\
\hline Description & $\begin{array}{l}\text { Settlement cycles } \\
\text { Trade transactions are settled on a rolling basis in the regulated market. The } \\
\text { settlement cycles are as follows: } \\
\text { - Equities: T+3. } \\
\text { - Government and corporate bonds: } \mathrm{T}+2 \text {. } \\
\text { OTC trades: negotiable between the involved counterparties, but the majority of these } \\
\text { transactions are settled on T+2. } \\
\text { Failed trades and facilities to smooth the settlement process } \\
\text { For the year } 2006 \text {, the number of failed settlements was very small. There were } 1,120 \\
\text { failed transactions on T+3, or } 0.0037 \text { percent of trading transactions or } 0.0456 \\
\text { percent of netting transactions. In terms of value of trades, settlement failure } \\
\text { amounted to B } 3,991 \text { million, or } 0.1 \text { percent of trading value or } 0.5750 \text { percent of net } \\
\text { settlement value. } \\
\text { For the first three months of } 2007 \text {, after the Government Pension Fund (GPF) became } \\
\text { the lender of last resort for the system, the proportion of failed trades has lowered to } \\
\text { 0.02 percent of trading value or } 0.14 \text { percent of netting value. } \\
\text { Incentives to settle in due time } \\
\text { TSD rules require clearing members who fail to settle their obligations on the } \\
\text { contractual date to contribute to the clearing fund in a greater amount than those who } \\
\text { can settle on the contractual date. } \\
\text { preving }+4 \text { (one day after regular settlement date) is used, in which closing prices of the } \\
\text { is higher. If such security is not available for buy-in, the buy-in bids are allowed to } \\
\text { linger on for up to four days with an addition of two spreads on the previous buy-in } \\
\text { price or closing price of the previous day or current best bid, whichever is higher } \\
\text { (until T+7). After that, if there is no offer, the defaulting member has to settle in cash } \\
\text { together with some penalty fees. } \\
\text { long }\end{array}$ \\
\hline
\end{tabular}




\begin{tabular}{|c|c|}
\hline & $\begin{array}{l}\text { Monitoring of fails } \\
\text { There are two steps for mitigating risks of fails. } \\
\text { (1) The TSD uses settlement cap to monitor the ability to settle trades of each } \\
\text { member. Settlement cap is defined as the maximum pending settlement value for } 3 \\
\text { days, which has to be no more than } 8 \text { times of net capital level as required by the } \\
\text { SEC. If the member has exposure higher than the limit, the TSD will call collateral in } \\
\text { cash for the exceeding limit. } \\
\text { (2) The TSD applies early warning system to predict possibility of members' causing } \\
\text { damage to the system. The system calculates the loss probability of each member by } \\
\text { using value-at-risk method. If any member has the loss probability more than } \\
5 \text { percent of confidence interval, such member is required to place collateral with the } \\
\text { TSD. Another warning tool is called financial surveillance system which applies } \\
\text { statistical tool to predict the financial status of members so that the TSD can assess } \\
\text { their future financial status at the earlier stage. } \\
\text { Analysis of shorter settlement cycles } \\
\text { A study on the feasibility of a shorter settlement cycle known as "STP Business Case } \\
\text { Study" has been analyzed. However, the study did not evaluate the cost and benefit of } \\
\text { the shorter cycle. The conclusion was that the straight-through processing would help } \\
\text { reduce manual interventions and bring about shorter settlement cycle, which can } \\
\text { result in a decrease in operational risk by approximately } 15 \text { percent. }\end{array}$ \\
\hline Assessment & Observed \\
\hline \multicolumn{2}{|l|}{ Comments } \\
\hline Recommendation 4. & $\begin{array}{l}\text { The benefits and costs of a central counterparty should be assessed. Where such a } \\
\text { mechanism is introduced, the central counterparty should rigorously control the risks } \\
\text { it assumes. }\end{array}$ \\
\hline Description & $\begin{array}{l}\text { TSD acts as central counterparty for equities transactions matched at the SET. It } \\
\text { interposes itself between the buyer and seller and guarantee that all of the obligations } \\
\text { will be honored. } \\
\text { At present, there is no CCP for bonds transactions. No cost benefit analysis has been } \\
\text { carrying aimed at assessing whether CCP should be introduced for bonds } \\
\text { transactions. } \\
\text { Netting arrangements } \\
\text { The netting arrangements are carried out on a novation basis. TSD interposes itself } \\
\text { between clearing members. This netting arrangement is enforceable under Sections } \\
341-348 \text { of the Civil and Commercial Code and Section } 102 \text { of the Bankruptcy Act } \\
\text { B.E. } 2483 \text {. However, since Section } 102 \text { of the Bankruptcy Act allows netting of } \\
\text { obligations only if the cause of indebtedness incurred before the date of the } \\
\text { receivership order, the TSD may not net its obligations against the obligations of the } \\
\text { insolvent participant which arise on that date. }\end{array}$ \\
\hline Assessment & Broadly observed \\
\hline Comments & This recommendation deals only with the cost-benefit analysis of introducing CCP. \\
\hline
\end{tabular}




\begin{tabular}{|c|c|}
\hline & $\begin{array}{l}\text { At present, there is a CCP for equities but not for government bonds. For the } \\
\text { observance of this recommendation, a cost-benefit analysis should be carried out } \\
\text { aimed at assessing whether CCP should be introduced for debt instruments } \\
\text { transactions. } \\
\text { The risk management procedures, efficiency, access, transparency, etc. are covered } \\
\text { by the CPSS/IOSCO Recommendations for CCP. } \\
\text { As an immediate measure, the CCP activities should be direct subject to the } \\
\text { regulation and supervision of the SEC. } \\
\text { The SEC is encouraged to assess the CCP function of TSD against the CPSS/IOSCO } \\
\text { Recommendations for CCP. }\end{array}$ \\
\hline Recommendation 5. & $\begin{array}{l}\text { Securities lending and borrowing (or repurchase agreements and other economically } \\
\text { equivalent transactions) should be encouraged as a method for expediting the } \\
\text { settlement of securities transactions. Barriers that inhibit the practice of lending } \\
\text { securities for this purpose should be removed. }\end{array}$ \\
\hline Description & $\begin{array}{l}\text { Institutional framework } \\
\text { Securities lending operations in Thailand are supported by comprehensive legislative } \\
\text { and regulatory frameworks, and accounting and tax systems. In particular, Anyone, } \\
\text { except the TSD, who intends to conduct the lending business shall apply for a license. } \\
\text { Besides, a Royal Decree regarding tax issues in relation to the SBL transactions has } \\
\text { been announced. } \\
\text { The Institute of Certified Accountants and Auditors of Thailand (ICAAT) has issued } \\
\text { an accounting guideline for the recording and disclosure of information on the } \\
\text { securities lending transactions since August 2003. Such guideline is preliminarily } \\
\text { based on two related International Accounting Standards (IAS) set by IAS No. 39) } \\
\text { and the U.S. Financial Accounting Standards Board (FASB No.140). } \\
\text { The securities lending transaction and collateral are exempted from tax exemption. } \\
\text { There is also a clear guideline for tax treatment on benefits arising from the securities } \\
\text { lending transactions. } \\
\text { Automated securities lending facilities } \\
\text { TSD has recently established a centralized securities lending facility to expedite } \\
\text { settlement. This facility is automated and activated in case of a securities shortage. } \\
\text { TSD assumes the role of a principal when providing securities lending. The } \\
\text { borrowers are general members of the TSD, which are brokers. The lenders are } \\
\text { depository members of the TSD, including institutional investors, mutual funds, } \\
\text { private funds and GPF. The GPF has agreed to be a lender of last resort from } \\
\text { February } 1 \text {, } 2007 \text {. } \\
\text { Supervision of the risk involved in securities lending } \\
\text { The SEC regulates and supervises securities borrowing and lending activities. A } \\
\text { license from the SEC is required in order to provide these services. The SEC }\end{array}$ \\
\hline
\end{tabular}




\begin{tabular}{|c|c|}
\hline & $\begin{array}{l}\text { performs onsite examination of borrowing and lending functions undertaken by } \\
\text { intermediaries. An applicant should maintain capital and reserve as required by law, } \\
\text { having efficient policies and measures for risk management and control that are } \\
\text { approved by the SEC, and having efficient borrowing and lending operating system. } \\
\text { Furthermore, policy measures with respect to risk management procedures are stated } \\
\text { in the SEC notification. For instance, intermediaries providing securities lending and } \\
\text { borrowing facility have to analyze counterparty risk and obtain collateral from the } \\
\text { borrowers. They must also have internal control and risk management system, which } \\
\text { is approved by the board of directors. }\end{array}$ \\
\hline Assessment & Observed \\
\hline Comments & $\begin{array}{l}\text { Nonresident investors are not allowed to borrow securities through commercial banks } \\
\text { which act as intermediaries/ custodians. Furthermore, nonresident investors must } \\
\text { place only foreign currency as collateral when acting as securities lender. However, } \\
\text { according to some custodians, the offshore securities lending between nonresidents in } \\
\text { Thailand securities is very active and substantial. It is worthwhile to reflect over these } \\
\text { restrictions as the participation of nonresident would contribute to the development of } \\
\text { the securities lending market and the liquidity in the capital market. }\end{array}$ \\
\hline Recommendation 6. & $\begin{array}{l}\text { Securities should be immobilized or dematerialized and transferred by book entry in } \\
\text { CSD to the greatest extent possible. }\end{array}$ \\
\hline Description & $\begin{array}{l}\text { Dematerialization and immobilization } \\
\text { The legal basis in Thailand supports the issuance of securities in a physical form. } \\
\text { There is no legal framework for dematerialization. Transfer of securities can be by } \\
\text { book entry or physical and securities holders can choose between these two forms. } \\
\text { Around } 74 \text { percent of listed securities and } 70 \text { percent of government bonds are } \\
\text { immobilized. TSD has encouraged the issuer to immobilize listed securities so as to } \\
\text { reduce the number of certificates and increase the transfer by book entry. } \\
\text { Transfer of title } \\
\text { TSD operates an indirect account holding system. Securities are kept under the name } \\
\text { of TSD, which acts as a nominee and the transfer of ownership occurs when the } \\
\text { securities are transferred among participants in the books of TSD, which notifies by } \\
\text { electronic message the intermediaries that the transfer has been registered in the } \\
\text { relevant accounts held by TSD. As soon as the intermediaries receive this } \\
\text { notification, intermediaries shall make the necessary entries in their accounts. } \\
\text { For government bonds, the BOT acts as the registrar while the TSD acts as the CSD. } \\
\text { Any transfer of securities in the CSD will have no effect on the registration system at } \\
\text { the BOT. On the closing date of the company's register, the TSD shall notify the } \\
\text { registrar the accounts of all deposited securities and the name list of holders of such } \\
\text { securities existed prior to the closing date. }\end{array}$ \\
\hline Assessment & Observed \\
\hline Comments & $\begin{array}{l}\text { A relatively high share of securities is still transferred in a physical form. This } \\
\text { increases the level of risk and settlement costs and reduces efficiency. } \\
\text { Immobilization and, in particular, dematerialization of securities and their transfer by }\end{array}$ \\
\hline
\end{tabular}




\begin{tabular}{|c|c|}
\hline & $\begin{array}{l}\text { book entry would significantly reduce the costs of settlement and custody. By } \\
\text { reducing cost and improving efficiency, book entry settlement supports the } \\
\text { development of the capital markets in Thailand. For this reason, the SEC together } \\
\text { with the BOT should explore the possibility to develop a regulatory framework for } \\
\text { dematerialized securities. }\end{array}$ \\
\hline Recommendation 7. & $\begin{array}{l}\text { Securities settlement systems should eliminate principal risk by linking securities } \\
\text { transfers to funds transfers in a way that achieves delivery versus payment. }\end{array}$ \\
\hline Description & $\begin{array}{l}\text { Legal framework } \\
\text { The DVP settlement is clearly set out in the TSD regulations. In practice and in TSD } \\
\text { regulation, members are required to deliver securities or make payment in the amount } \\
\text { shown in the netting report. If not, the TSD will suspend the transfer of securities in } \\
\text { the securities depository account of the defaulting members or the payment for } \\
\text { securities which the defaulting members are entitled to receive. } \\
\text { Technical framework } \\
\text { The TSD system is based on two DVP modalities: Real Time Gross Settlement } \\
\text { (RTGS), and Net Settlement, where both the cash and securities are netted. } \\
\text { Both RTGS and Net Settlement functionalities are based on DVP mechanism, where } \\
\text { the settlement of the cash and securities is executed simultaneously. The settlement of } \\
\text { securities takes place by book entry on the securities accounts held by participants at } \\
\text { TSD and the settlement of cash is carried out in central bank money through a real } \\
\text { time link to the BAHTNET system (RTGS Payment system) operated by BOT. } \\
\text { The system has one net settlement batch which is executed at 2:15 p.m. The RTGS } \\
\text { system is available throughout the day between 8:00am and 5:00 p.m. } \\
\text { The RTGS system settles bonds transactions. The RTGS system processes the } \\
\text { transactions according to the following procedures: } \\
\text { c) If there is insufficient availability in the account with BOT, the transaction is } \\
\text { routed to the queuing system. If the transaction is cancelled from } \\
\text { BATHNET system, the RTGS system deletes the transaction and removes } \\
\text { the block previously put on the seller's securities account. } \\
\text { is positive, places an accounting block equal to the negotiated quantity, until } \\
\text { receiving notification that the cash settlement from BOT is completed; } \\
\text { b) if the seller's securities account has insufficient availability, the TSD will } \\
\text { not send payment instruction to the BOT. }\end{array}$ \\
\hline Assessment & Observed \\
\hline Comments & \\
\hline Recommendation 8. & $\begin{array}{l}\text { Final settlement on a DVP basis should occur no later than the end of the settlement } \\
\text { day. Intra-day or real-time finality should be provided where necessary to reduce } \\
\text { risks. }\end{array}$ \\
\hline Description & $\begin{array}{l}\text { Intraday finality } \\
\text { TSD provides real time finality and intraday finality. In fact, the RTGS allows real }\end{array}$ \\
\hline
\end{tabular}




\begin{tabular}{|c|c|}
\hline & $\begin{array}{l}\text { time finality after the execution of DVP settlement. For the net batch, finality is } \\
\text { achieved at 2:00 p.m. For transactions received after this time and when there is a } \\
\text { need for the same day delivery, settlement is carried out by the RTGS system. } \\
\text { Monetary policy operations are settled by the RTGS system and finality is achieved } \\
\text { through out the day on a real time basis. } \\
\text { All settlement and book-entry transfer procedures offer real-time or intra-day finality. } \\
\text { The intra-day and real time finality are at the complete disposal of each participant } \\
\text { and can be used by both trading parties and the CCP in order to manage their risks } \\
\text { efficiently or to facilitate the smooth functioning of markets. } \\
\text { Revocation of unsettled transaction } \\
\text { The TSD does not allow the unilateral revocation of unsettled transfer instructions } \\
\text { late in the settlement day. }\end{array}$ \\
\hline Assessment & Observed \\
\hline Comments & \\
\hline Recommendation 9. & $\begin{array}{l}\text { CSDs that extend intraday credit to participants, including CSDs that operate net } \\
\text { settlement systems, should institute risk controls that, at a minimum, ensure timely } \\
\text { settlement in the event that the participant with the largest payment obligation is } \\
\text { unable to settle. The most reliable set of controls is a combination of collateral } \\
\text { requirements and limits. }\end{array}$ \\
\hline Description & $\begin{array}{l}\text { Measures to ensure settlement } \\
\text { TSD offers two types of settlement, RTGS and central counterparty (CCP). The } \\
\text { RTGS facility is a real time settlement process where trade is settled with immediate } \\
\text { finality. In the event that the participant does not have the securities or the cash the } \\
\text { settlement will not take place unless the participant is eligible for securities lending } \\
\text { and/or intraday credit from BOT. As mentioned under Recommendation 5, TSD } \\
\text { operates securities lending facility. } \\
\text { As a CCP, TSD interposes itself as counterparty between the seller and buyer. It } \\
\text { ensures timely settlement by using the credit line from settlement bank to handle the } \\
\text { default of payment, and borrowing process and then buy-in process to handle the } \\
\text { default of listed securities. Moreover, the clearing fund and reserve fund from the } \\
\text { SET are also provided when necessary. Furthermore, TSD can call for collateral fully } \\
\text { when the member's exposure exceeds the limit (Settlement cap in excess of eight } \\
\text { times net capital). The outstanding balances of each member are marked to market } \\
\text { daily. TSD limits the credit extension of each member to not more than eight times of } \\
\text { each member's net capital value. As a CCP, TSD has access to liquidity resources to } \\
\text { ensure timely settlement. } \\
\text { TSD evaluates the probability of multiple failures by conducting stress testing on a } \\
\text { quarterly basis to ensure the settlement completion. A stress test is run by assuming } \\
99 \text { percent confidence level; maximum loss is caused by failure of } 14 \text { members; } \\
\text { volatility of SET index is at } 2.65 \text {. The result shows that possible maximum loss } \\
\text { equals to B } 1,860 \text { million at the daily trading volume of B } 74,000 \text { million and the } \\
\text { clearing fund can cover multiple failures during the most volatile period. }\end{array}$ \\
\hline
\end{tabular}




\begin{tabular}{|c|c|}
\hline & $\begin{array}{l}\text { Overdraft or debit balances } \\
\text { TSD permits debit balances in equities. However, the amount has been very small, } \\
\text { i.e., } 0.1 \text { percent of trading value or } 0.57 \text { percent of netting value or } 0.05 \text { percent of } \\
\text { netting transactions in } 2006 \text {. The TSD has tried to minimize debit balances of equities } \\
\text { by increasing the use of securities lending facility. Since February } 2007 \text {, the amount } \\
\text { of debit balance has declined to } 0.02 \text { percent of trading value or } 0.14 \text { percent of } \\
\text { netting value as of February } 28,2007 \text {. }\end{array}$ \\
\hline Assessment & Non-observed \\
\hline Comments & $\begin{array}{l}\text { For the observance of this recommendation TSD should abolish debit balances in } \\
\text { securities. } \\
\text { In addition, the CCP and CSD functions are integrated within TSD. The role of the } \\
\text { CCP is to assume the principal risk, while that of the CSD is to avoid credit and } \\
\text { liquidity risks. The CSD has a central function in the capital market as it is the } \\
\text { ultimate settlement entity. In order to protect the CSD from any contagious risk } \\
\text { inherited in CCP activities, it should considered to separating the CCP function from } \\
\text { the CSD function, by setting up a distinct legal entity that provides CCP services. }\end{array}$ \\
\hline Recommendation 10. & $\begin{array}{l}\text { Assets used to settle the cash leg of securities transactions between CSD members } \\
\text { should carry little or no credit risk. if central bank money is not used, steps must be } \\
\text { taken to protect CSD members from potential losses and liquidity pressures arising } \\
\text { from the failure of a settlement bank. }\end{array}$ \\
\hline Description & $\begin{array}{l}\text { Multi-tiered structure } \\
\text { Cash settlement in TSD is based on a multi-tiered structure. Banks that have access to } \\
\text { BOT account settle in central bank money. Participants that are not eligible for cash } \\
\text { accounts at the BOT rely on banks for the settlement of the cash leg of the } \\
\text { transactions. There are } 3 \text { settlement banks acting as settlement agents for the cash } \\
\text { clearing of securities transactions, which are Siam Commercial Bank, Krung } \\
\text { Thailand Bank and Bangkok Bank. Their share of the cash settlement is } 65,25 \text {, and } \\
10 \text { percent, respectively. } \\
\text { Settlement bank risk } \\
\text { There are no specific rules and requirements set by TSD, BOT or SEC for settlement } \\
\text { agents' financial soundness. However, settlement agents are banks and subject to } \\
\text { prudential supervision by the BOT. According to a Memorandum of Understanding } \\
\text { (MOU) signed between the BOT and SEC, the BOT will inform the SEC on any } \\
\text { financial difficulties faced by a settlement agent. The SEC has also the possibility to } \\
\text { pass on this information to the TSD in order to protect the integrity of the settlement } \\
\text { system. } \\
\text { Same day funds } \\
\text { Proceeds of securities settlements, i.e., cash and securities, can be used immediately, } \\
\text { as soon as they are credited on the participants' cash/securities accounts. Participants } \\
\text { shall also transfer to their clients via Automatic Transfer System for Securities } \\
\text { Settlement (ATS) on the same day. }\end{array}$ \\
\hline
\end{tabular}




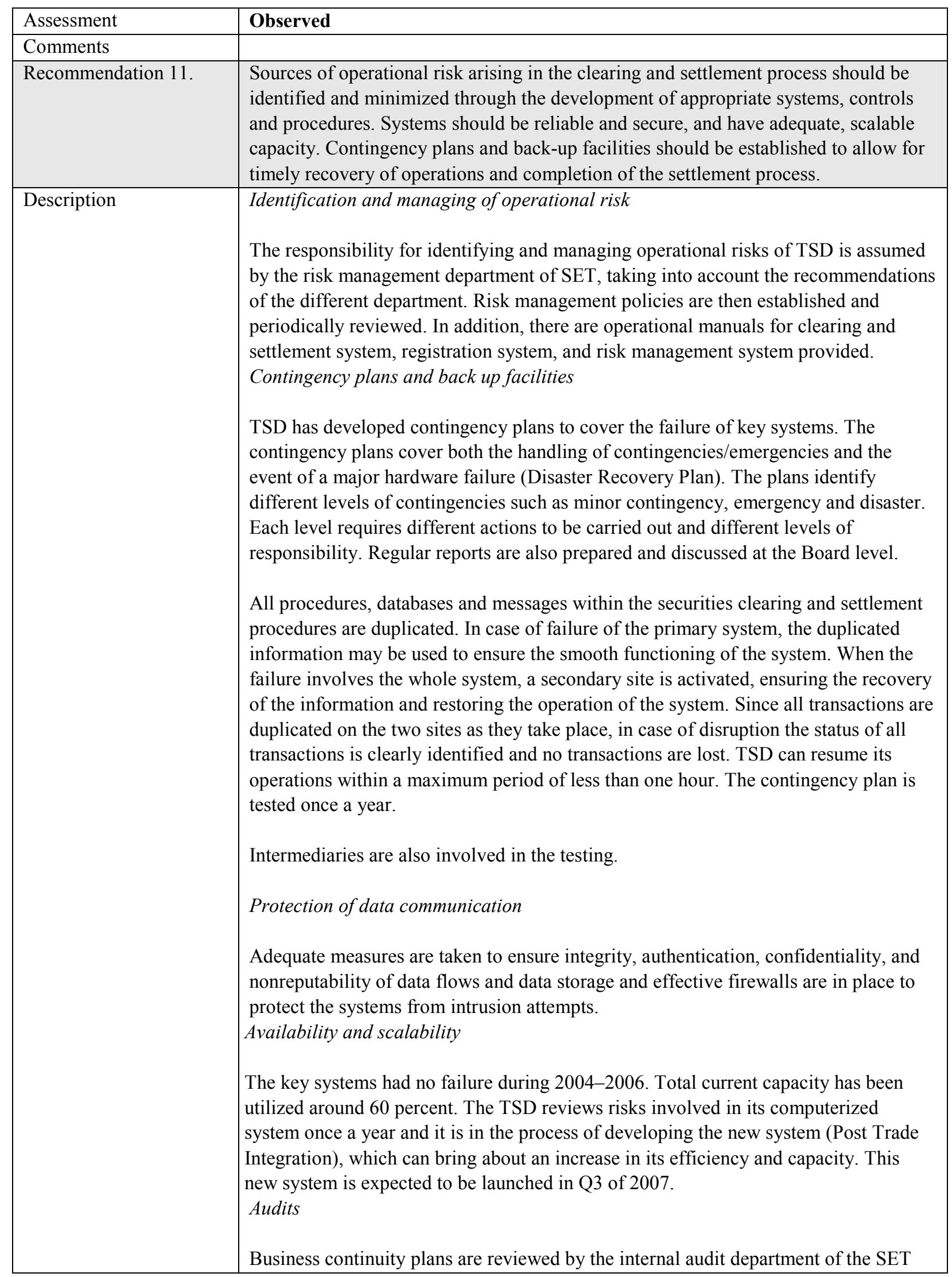




\begin{tabular}{|c|c|}
\hline & $\begin{array}{l}\text { and external auditor. Each department is responsible for evaluating the operational } \\
\text { risk of its own. The internal audit department of the SET then conducts a review } \\
\text { again by risk-based audit. The audit report on the TSD will then be sent to TSD } \\
\text { management and board and up to the Board of the SET. Moreover, there is an } \\
\text { external audit team from PricewaterhouseCoopers who is responsible for conducting } \\
\text { an audit and review on overall procedural risks of the TSD. }\end{array}$ \\
\hline Assessment & Observed \\
\hline Comments & $\begin{array}{l}\text { SEC should receive a copy of the internal and external audit of TSD policy and } \\
\text { procedures to handle operational risk. }\end{array}$ \\
\hline Recommendation 12. & $\begin{array}{l}\text { Entities holding securities in custody should employ accounting practices and } \\
\text { safekeeping procedures that fully protect customers' securities. It is essential that } \\
\text { customers' securities be protected against the claims of a custodian's creditors. }\end{array}$ \\
\hline Description & $\begin{array}{l}\text { Legal protection of customers assets } \\
\text { Several technical and institutional arrangements are in place in order to ensure the } \\
\text { protection of the customers' securities. In particular, the regulation of TSD obliges } \\
\text { the participants to segregate their assets from those of the customers. } \\
\text { Furthermore, intermediaries holding securities in custody are obliged to reconcile the } \\
\text { securities held in their records once a day for the book entry and once a month for the } \\
\text { immobilized securities. In addition, intermediaries carry out internal audit to ensure } \\
\text { sufficiency of securities to satisfy customer claims. } \\
\text { Supervision and regulation } \\
\text { Market intermediaries are subject to the regulation of SEC and custodians banks } \\
\text { holding securities on behalf of their customers are subject to rigorous regulations and } \\
\text { supervision by the BOT. In particular, they are subject to specific rules on } \\
\text { safekeeping and protection of customer's assets. SEC performs onsite examination on } \\
\text { market intermediaries periodically. SEC does the onsite audit on the participants' } \\
\text { securities account balance regularly. The frequency of audit depends on the risked } \\
\text { based approach criteria. }\end{array}$ \\
\hline Assessment & Observed \\
\hline Comments & $\begin{array}{l}\text { SEC and BOT should cooperate in order to ensure that custodian banks are } \\
\text { implementing the necessary measures to protect the customer's assets. }\end{array}$ \\
\hline Recommendation 13. & $\begin{array}{l}\text { Governance arrangements for CSD and central counterparties should be designed to } \\
\text { fulfill public interest requirements and to promote the objectives of owners and users. }\end{array}$ \\
\hline Description & $\begin{array}{l}\text { Internal governance arrangements } \\
\text { TSD is a subsidiary of the SET. TSD has its own board composed mainly of } \\
\text { representatives from SET. Similar to other companies incorporated in Thailand, the } \\
\text { corporate body of TSD is the Shareholder's Meeting and the Board of Directors. It is } \\
\text { currently composed of } 11 \text { members, which comprises chairman of the SET board, } \\
\text { President and Vice President of the SET, President of the TSD, two directors of the } \\
\text { SET board (one elected by SET members, another one appointed by the SEC), and } \\
\text { five external experts from customers/users such as fund managers or related } \\
\text { government organizations such as the BOT. The responsibilities of the Board are }\end{array}$ \\
\hline
\end{tabular}




\begin{tabular}{|c|c|}
\hline & $\begin{array}{l}\text { established by the Thai civil law, which implies that all members of the Board are } \\
\text { jointly liable for damages toward the company. } \\
\text { The annual report of TSD contains comprehensive information on TSD, the } \\
\text { ownership, boards and management structure, financial results and status, } \\
\text { development and achievement. This information is also available on its web site. } \\
\text { Users participation } \\
\text { TSD maintains close working relationships with professional Association such as the } \\
\text { Association of Securities Companies, Banking Association, etc. TSD carries out } \\
\text { consultation with users on a regular basis. Participants are also invited to share the } \\
\text { analysis and development stages of new projects and participate in tests and } \\
\text { validations before new applications become operational. Information about major } \\
\text { decisions (new regulations, services, projects, changes in pricing, etc.) is provided in } \\
\text { writing and sent to all participants in advance of the effective date. } \\
\text { Management incentives } \\
\text { The achievement of the managers (by area of responsibility) is monitored and } \\
\text { measured by senior management. The skills of personnel are kept updated through a } \\
\text { number of seminars, conferences and internal training initiatives. }\end{array}$ \\
\hline Assessment & Broadly observed \\
\hline Comments & $\begin{array}{l}\text { The majority of the board members of TSD are nominated by SET. Furthermore, SEC } \\
\text { supervisory power on TSD is limited and is rather indirect exercised through the SET } \\
\text { board. This gives SET a strong influence on the function and operation of TSD. } \\
\text { Consequently, the current governance structure of TSD may not entirely serve the } \\
\text { interest of TSD users, in particular, as many of them are not members of the stock } \\
\text { exchange. This may lead to conflict between the interest of SET and that of TSD. } \\
\text { For the compliance with this recommendation, the Governance structure of TSD } \\
\text { should be strengthened by appointing more independent board members and by not } \\
\text { being subject to the "regulation power" of the Board of SET. }\end{array}$ \\
\hline Recommendation 14. & $\begin{array}{l}\text { CSD and central counterparties should have objective and publicly disclosed criteria } \\
\text { for participation that permit fair and open access. }\end{array}$ \\
\hline Description & $\begin{array}{l}\text { Access criteria } \\
\text { The access criteria to TSD are objective and clearly disclosed on its website. The } \\
\text { criteria of TSD permit fair and open access to all financial intermediaries. However, } \\
\text { TSD accepts only direct participant located in Thailand. This is justified by the need } \\
\text { to limit the system's exposure to the risks associated with cross-border activities. } \\
\text { Information about new regulations is immediately given to all participants through } \\
\text { specific means of communications. } \\
\text { Participants in TSD can have access to the clearing function, CSD function, } \\
\text { settlement system or all three functionalities. Membership requirements are the same } \\
\text { regardless of the identity and category of the applicant. }\end{array}$ \\
\hline
\end{tabular}




\begin{tabular}{|c|c|}
\hline & $\begin{array}{l}\text { Exit criteria } \\
\text { The TSD rules and conditions define cases for termination or temporary suspension } \\
\text { of membership. These cases are: } \\
\text { - } \quad \text { The broker/dealer license has been revoked; } \\
\text { - } \quad \text { Failure to contribute fund to the clearing fund or other fees as prescribed by the } \\
\text { TSD; } \\
\text { - } \quad \text { Failure to comply with risk management process as defined by the TSD; } \\
\text { - } \quad \text { Inability to comply with rules, regulations, conditions prescribed by the TSD; } \\
\text { - Having the operation of financial condition that might be detrimental to the } \\
\text { clearing and settlement of securities among the clearinghouse members; and } \\
\text { - Members having requested termination of their participation in TSD. } \\
\text { TSD has in place steps to facilitate the orderly exit of members who no longer meet } \\
\text { the requirements. Members who request to terminate or are ordered to terminate their } \\
\text { membership must complete all of their obligations before they leave the system. The } \\
\text { conditions for termination or temporary suspension of membership are publicly } \\
\text { available on the web site in both Thai and English language. }\end{array}$ \\
\hline Assessment & Observed \\
\hline Comments & $\begin{array}{l}\text { The TSD may consider opening its system to foreign participants. Appropriate risk } \\
\text { management procedures could be defined and put in place in order to monitor and } \\
\text { manage the risks associated with cross-border activities. The participation of foreign } \\
\text { participants would contribute to the development of the Thailand capital market. }\end{array}$ \\
\hline Recommendation 15. & $\begin{array}{l}\text { While maintaining safe and secure operations, recommendations securities settlement } \\
\text { systems (RSSS) should be cost-effective in meeting the requirements of users. }\end{array}$ \\
\hline Description & $\begin{array}{l}\text { Budgetary process, price structure and benchmarking } \\
\text { TSD settlement fees are integrated into the aggregated fees collected by the parent } \\
\text { company, SET. A large share of TSD costs is covered by revenues generated from the } \\
\text { registrar and custody functions. There is clearly a risk of cross subsidizing; that } \\
\text { means the customers using only the custody services of TSD are subsidizing the } \\
\text { settlement function of TSD. Furthermore, as settlement fee is bundled in trading fee } \\
\text { charged by SET, TSD hasn't had benchmark its prices against other CSDs in the } \\
\text { region. } \\
\text { Since a large share of TSD fees are integrated in those of the stock exchange, TSD } \\
\text { does not have in place procedures to regularly review its pricing levels against its } \\
\text { costs of operation. } \\
\text { Reviewing service levels } \\
\text { The service levels are reviewed annually by surveying users and owners (information } \\
\text { technology of SET). Dedicated business and technical customer support departments } \\
\text { provide support and problem resolution related to service issues. Feedback from } \\
\text { participants is taken into account in creating customer satisfaction index, which helps } \\
\text { the TSD to measure satisfaction of its participants. }\end{array}$ \\
\hline
\end{tabular}




\begin{tabular}{|c|c|}
\hline & $\begin{array}{l}\text { Operational reliability and capacity levels } \\
\text { The TSD has procedures to review operational reliability including adequacy of its } \\
\text { capacity. Operational reliability and possible malfunctioning are also systematically } \\
\text { checked on a regular basis. }\end{array}$ \\
\hline Assessment & Non-observed \\
\hline Comments & $\begin{array}{l}\text { For compliance with this recommendation the pricing structure of TSD should be } \\
\text { separated from that of the stock exchange, and TSD should have in place procedures } \\
\text { to regularly review its pricing levels against costs of operation. This measure would } \\
\text { eliminate any risk of cross subsidizing and would increase transparency of the } \\
\text { pricing/costs structure. }\end{array}$ \\
\hline Recommendation 16. & $\begin{array}{l}\text { Securities settlement systems should use or accommodate the relevant international } \\
\text { communication procedures and standards in order to facilitate efficient settlement of } \\
\text { cross-border transactions. }\end{array}$ \\
\hline Description & $\begin{array}{l}\text { TSD uses proprietary communication network for securities listed on the SET. At } \\
\text { present, this network does not offer high level of data transfer protection and data can } \\
\text { be converted into international standards with considerable difficulty. } \\
\text { For government bonds, Society for Worldwide Interbank Financial } \\
\text { Telecommunication (SWIFT) message is used and TSD has already subscribed to } \\
\text { SWIFTNET for communication and linked its system to those of the BOT. } \\
\text { TSD is in the process of developing post trade integrated platform, which will use } \\
\text { international standards procedures and standards. }\end{array}$ \\
\hline Assessment & Partly observed \\
\hline Comments & $\begin{array}{l}\text { For the observance of this recommendation, TSD should enhance its proprietary } \\
\text { network to meet international procedures and standards. }\end{array}$ \\
\hline Recommendation 17. & $\begin{array}{l}\text { CSD and central counterparties should provide market participants with sufficient } \\
\text { information for them to accurately identify the risks and costs associated with using } \\
\text { the CSD or central counterparty services. }\end{array}$ \\
\hline Description & $\begin{array}{l}\text { Availability or rules, regulations etc. } \\
\text { Laws, regulations, systems' rules, and fees are part of the contractual agreements } \\
\text { which are to be signed by participants. In particular, participants' rights, obligations } \\
\text { and costs are defined in these documents, which are also available, on TSD website. } \\
\text { TSD risks and steps taken to mitigate them are described in the Business Continuity } \\
\text { and Contingency Plan, also available on the website and through official documents } \\
\text { available to participants. } \\
\text { CPSS/IOSCO disclosure framework } \\
\text { TSD indicated that it has completed the questionnaire set out in the CPSS/IOSCO } \\
\text { disclosure framework and answered the key questions in this methodology, but it has } \\
\text { not disclosed the answers to the public. However, the SEC intends to publish the } \\
\text { answers of key question in RSSS methodology in SEC website. }\end{array}$ \\
\hline
\end{tabular}




\begin{tabular}{|c|c|}
\hline Assessment & Observed \\
\hline Comments & \\
\hline Recommendation 18. & $\begin{array}{l}\text { Securities settlement systems should be subject to regulation and oversight. The } \\
\text { responsibilities and objectives of the securities regulator and the central bank with } \\
\text { respect to RSSS should be clearly defined, and their roles and major policies should } \\
\text { be publicly disclosed. They should have the ability and resources to perform their } \\
\text { responsibilities, including assessing and promoting implementation of these } \\
\text { recommendations. They should cooperate with each other and with other relevant } \\
\text { authorities. }\end{array}$ \\
\hline Description & $\begin{array}{l}\text { Entities involved in the oversight/supervision } \\
\text { Under the SEA, the SEC has the power to: } \\
\text { - grant clearinghouse license to the clearinghouse (Section 219); } \\
\text { - determine rules applied to the clearinghouse (Section 223); } \\
\text { - approve operating rules, conditions and procedures issued by the board of directors } \\
\text { of the SET governing the clearing house function of the SET or SET's subsidiary } \\
\text { (Section 224); and } \\
\text { - restrict some activities of the TSD as a clearinghouse that may cause damage to the } \\
\text { public by exercising power through the SET's board of directors. (Section 186). } \\
\text { However, SEC does not have the legal power to directly regulate and supervise TSD. } \\
\text { In order to influence the design and operation of TSD, SEC needs to rely on the SET. } \\
\text { Despite the limitation of legal power, SEC has carried out several examinations on } \\
\text { the performance of the TSD with emphasis on its functions and the risks associated } \\
\text { with its activities. SEC communicates the results of its investigation either informally } \\
\text { or formally to the TSD and SET Board of Directors, encouraging them to take } \\
\text { appropriate actions and to report the remedial actions to the SEC. } \\
\text { TSD is not subject to the oversight responsibility of the BOT, which currently does } \\
\text { not have any clear policies and objectives for securities clearing and settlement } \\
\text { systems. } \\
\text { Roles, responsibilities and resources } \\
\text { The SEC has } 421 \text { staff, } 23 \text { percent of which achieve degrees in finance, 17 percent in } \\
\text { accountancy, and the rest in laws and economy. The SEC also has sufficient funding } \\
\text { for its operation, with funds generated from industry fees it sets and collects. In case } \\
\text { of a budgetary shortfall, the SEC has a permanent endowment that may be used. } \\
\text { addressing financial disruption and to share information on relevant prudential issues, } \\
\text { has not yet been implemented. } \\
\text { Coopetween relevant authorities }\end{array}$ \\
\hline
\end{tabular}




\begin{tabular}{|c|c|}
\hline & $\begin{array}{l}\text { Cross-border cooperation } \\
\text { There is a framework for cooperation with the regulators outside the country such as } \\
\text { Hong Kong, Special Administrative Region (SAR) Malaysia, Australia, and Taiwan } \\
\text { Province of China (POC), etc. }\end{array}$ \\
\hline Assessment & Partly observed \\
\hline Comments & $\begin{array}{l}\text { For the observance of this recommendation, the following measure need to } \\
\text { implemented: } \\
\text { SEC should have the legal power to directly regulate and supervise TSD without the } \\
\text { involvement of the Board of SET. } \\
\text { The BOT should assume its oversight responsibility of TSD and should set put a } \\
\text { dedicated team to oversee the activities of TSD. } \\
\text { The SEC and BOT should develop a cooperation framework that identifies the } \\
\text { responsibilities of each authority, aimed at avoiding overlapping and loopholes. This } \\
\text { framework should specify clearly the tasks of each authority, areas where both } \\
\text { authorities have common interests, exchange of information, etc. For instance and in } \\
\text { line with international experience, the BOT would be responsible for the containment } \\
\text { of systemic risk and the soundness of clearing and settlement systems, while SEC } \\
\text { would be responsible for the proper conduct, protection of investors, governance, } \\
\text { access and transparency. } \\
\text { In order to increase the effectiveness of their cooperation and strengthening their } \\
\text { overall supervision and oversight roles, the SEC and the BOT need to increase their } \\
\text { mutual understandings of respective regulatory objectives and needs. } \\
\text { SEC and BOT should enhance the capacity of their staff by setting up dedicating } \\
\text { team in respective authority to deal with securities clearing and settlement systems. } \\
\text { The members of these teams should be offered specific courses, seminars and on-job } \\
\text { training. }\end{array}$ \\
\hline Recommendation 19. & $\begin{array}{l}\text { CSDs that establish links to settle cross-border trades should design and operate such } \\
\text { links to reduce effectively the risks associated with cross-border settlement. }\end{array}$ \\
\hline Description & TSD does not have cross-border link to foreign CSDs. \\
\hline Assessment & Not applicable \\
\hline Comments & \\
\hline
\end{tabular}


Table 2. Summary Observance of TSD of the CPSS-IOSCO Recommendations for Securities Settlement Systems

\begin{tabular}{|c|c|c|}
\hline Responsibility & Grading & Comments \\
\hline \multicolumn{3}{|l|}{ Legal risk } \\
\hline $\begin{array}{l}\text { 1. Securities settlement systems should } \\
\text { have a well-founded, clear and } \\
\text { transparent legal basis in the relevant } \\
\text { jurisdiction. }\end{array}$ & $\mathrm{BO}$ & $\begin{array}{l}\text { The contractual arrangements between TSD } \\
\text { and its participants are fully enforceable } \\
\text { under the Civil and Commercial Code. } \\
\text { Netting arrangements can be challenged in } \\
\text { the event of bankruptcy. }\end{array}$ \\
\hline \multicolumn{3}{|l|}{ Pre-settlement risk } \\
\hline $\begin{array}{l}\text { 2. Confirmation of trades between market } \\
\text { participants should occur as soon as } \\
\text { possible after trade execution, but no later } \\
\text { than the trade date }(\mathrm{T}+0) \text {. Where } \\
\text { confirmation of trades by indirect market } \\
\text { participants (such as institutional } \\
\text { investors) is required, it should occur as } \\
\text { soon as possible after trade execution, } \\
\text { preferably on } \mathrm{T}+0 \text {, but no later than } \mathrm{T}+1 \text {. }\end{array}$ & $\mathrm{O}$ & $\begin{array}{l}\text { Trade confirmation for regulated markets } \\
\text { occurs the say day between direct } \\
\text { participants, while it is not mandatory for } \\
\text { indirect participants. For OTC transactions, } \\
\text { market convention is to confirm the trade the } \\
\text { same date. However, market participants } \\
\text { may agree to confirm at a later stage. }\end{array}$ \\
\hline $\begin{array}{l}\text { 3. Rolling settlement should be adopted } \\
\text { in all securities markets. Final settlement } \\
\text { should occur no later than } \mathrm{T}+3 \text {. The } \\
\text { benefits and costs of a settlement cycle } \\
\text { shorter than } \mathrm{T}+3 \text { should be assessed. }\end{array}$ & $\mathrm{O}$ & $\begin{array}{l}\text { Trade transactions are settled on a rolling } \\
\text { basis in the regulated market and the } \\
\text { settlement cycle for equities is } \mathrm{T}+3 \text { and for } \\
\text { debt instrument } \mathrm{T}+2 \text {. The settlement date for } \\
\text { OTC transactions is negotiable, but the } \\
\text { current convention is to settle on } \mathrm{T}+2 \text {. }\end{array}$ \\
\hline $\begin{array}{l}\text { 4. The benefits and costs of a central } \\
\text { counterparty should be assessed. Where } \\
\text { such a mechanism is introduced, the } \\
\text { central counterparty should rigorously } \\
\text { control the risks it assumes. }\end{array}$ & $\mathrm{BO}$ & $\begin{array}{l}\text { TSD acts as a CCP for equities. No costs } \\
\text { benefit analysis has been done for } \\
\text { introducing CCP for debt instruments. } \\
\text { The risk management procedures of TSD as } \\
\text { a CCP have not yet been assessed against } \\
\text { the CPSS/IOSCO recommendations for } \\
\text { CCP. } \\
\text { The CCP activities are currently not subject } \\
\text { to the regulation and supervision of the SEC. }\end{array}$ \\
\hline
\end{tabular}




\begin{tabular}{|c|c|c|}
\hline Responsibility & Grading & Comments \\
\hline $\begin{array}{l}\text { 5. Securities lending and borrowing (or } \\
\text { repurchase agreements and other } \\
\text { economically equivalent transactions) } \\
\text { should be encouraged as a method for } \\
\text { expediting the settlement of securities } \\
\text { transactions. Barriers that inhibit the } \\
\text { practice of lending securities for this } \\
\text { purpose should be removed. }\end{array}$ & $\mathrm{O}$ & $\begin{array}{l}\text { TSD has introduced securities lending and } \\
\text { borrowing facilities, although the activity is } \\
\text { relatively negligible. Furthermore, there is } \\
\text { no active securities lending market, such as a } \\
\text { repurchase agreement in Thailand. }\end{array}$ \\
\hline \multicolumn{3}{|l|}{ Settlement risk } \\
\hline $\begin{array}{l}\text { 6. Securities should be immobilized or } \\
\text { dematerialized and transferred by book } \\
\text { entry in CSD to the greatest extent } \\
\text { possible. }\end{array}$ & $\mathrm{O}$ & $\begin{array}{l}\text { A relatively high share of securities is still } \\
\text { transferred in physical form. This increases } \\
\text { the level of risk and settlement costs as well } \\
\text { as reduces efficiency. } \\
\text { Immobilization and, in particular, } \\
\text { dematerialization of securities and their } \\
\text { transfer by book entry would significantly } \\
\text { reduce costs and increase the efficiency of } \\
\text { settlement and custody. }\end{array}$ \\
\hline $\begin{array}{l}\text { 7. Securities settlement systems should } \\
\text { eliminate principal risk by linking } \\
\text { securities transfers to funds transfers in a } \\
\text { way that achieves delivery versus } \\
\text { payment. }\end{array}$ & $\mathrm{O}$ & $\begin{array}{l}\text { TSD provides DVP facility for the execution } \\
\text { of settlement. }\end{array}$ \\
\hline $\begin{array}{l}\text { 8. Final settlement on a DVP basis should } \\
\text { occur no later than the end of the } \\
\text { settlement day. Intra-day or real-time } \\
\text { finality should be provided where } \\
\text { necessary to reduce risks. }\end{array}$ & $\mathrm{O}$ & $\begin{array}{l}\text { TSD provides both intraday and end-of-day } \\
\text { settlement finality. }\end{array}$ \\
\hline $\begin{array}{l}\text { 9. CSDs that extend intraday credit to } \\
\text { participants, including CSDs that operate } \\
\text { net settlement systems, should institute } \\
\text { risk controls that, at a minimum, ensure } \\
\text { timely settlement in the event that the } \\
\text { participant with the largest payment } \\
\text { obligation is unable to settle. The most } \\
\text { reliable set of controls is a combination } \\
\text { of collateral requirements and limits. }\end{array}$ & NO & $\begin{array}{l}\text { TSD permits debit balances in securities. } \\
\text { This means securities which have not yet } \\
\text { been delivered to the system are booked on } \\
\text { the accounts of the participants. } \\
\text { In addition, the CSD functions- } \\
\text { registration, settlement and custody-are } \\
\text { integrated with the CCP function of TSD. } \\
\text { This means that CSD is exposed to the } \\
\text { principle risk inherited in CCP activities. As } \\
\text { best practice, the CCP function is separated } \\
\text { from the CSD functions, and the former one } \\
\text { is provided by a distinct legal entity. }\end{array}$ \\
\hline
\end{tabular}




\begin{tabular}{|c|c|c|}
\hline Responsibility & Grading & Comments \\
\hline $\begin{array}{l}\text { 10. Assets used to settle the cash leg of } \\
\text { securities transactions between CSD } \\
\text { members should carry little or no credit } \\
\text { risk. If Central Bank money is not used, } \\
\text { steps must be taken to protect CSD } \\
\text { members from potential losses and } \\
\text { liquidity pressures arising from the } \\
\text { failure of a settlement bank. }\end{array}$ & $\mathrm{O}$ & $\begin{array}{l}\text { The cash leg of the transactions is settled in } \\
\text { central bank money. However, the } \\
\text { settlement risk is concentrated in the three } \\
\text { major banks. }\end{array}$ \\
\hline \multicolumn{3}{|l|}{ Operational risk } \\
\hline $\begin{array}{l}\text { controls and procedures. Systems should } \\
\text { be reliable and secure, and have adequate, } \\
\text { scalable capacity. Contingency plans and } \\
\text { back-up facilities should be established to } \\
\text { allow for timely recovery of operations } \\
\text { and completion of the settlement process. }\end{array}$ & $\mathrm{O}$ & $\begin{array}{l}\text { TSD has adequate measures in place in order } \\
\text { to identify and monitor operational risk. It } \\
\text { also has developed a contingency plan that } \\
\text { ensures the system can resume on short } \\
\text { notice and the information can be retrieved. } \\
\text { The procedures are tested on a regular basis } \\
\text { and market participants are involved in the } \\
\text { testing. }\end{array}$ \\
\hline \multicolumn{3}{|l|}{ Custody risk } \\
\hline $\begin{array}{l}\text { 12. Entities holding securities in custody } \\
\text { should employ accounting practices and } \\
\text { safekeeping procedures that fully protect } \\
\text { customers' securities. It is essential that } \\
\text { customers' securities be protected against } \\
\text { the claims of a custodian's creditors. }\end{array}$ & $\mathrm{O}$ & $\begin{array}{l}\text { Adequate measures and arrangements are in } \\
\text { place to ensure the protection of the } \\
\text { customers' securities. In particular, the } \\
\text { regulation of TSD obliges the participants to } \\
\text { segregate their assets from those of the } \\
\text { customers and reconciliation is done on a } \\
\text { regular basis. }\end{array}$ \\
\hline \multicolumn{3}{|l|}{ Other issues } \\
\hline $\begin{array}{l}\text { 13. Governance arrangements for CSDs } \\
\text { and central counterparties should be } \\
\text { designed to fulfill public interest } \\
\text { requirements and to promote the } \\
\text { objectives of owners and users. }\end{array}$ & $\mathrm{BO}$ & $\begin{array}{l}\text { SET appoints the majority of the TSD board } \\
\text { and defines its policy and objectives. SET } \\
\text { has also the power to specify the issues, } \\
\text { conditions and procedures of TSD. This } \\
\text { create a conflict of interest, as the interest of } \\
\text { SET may not be compatible with that of } \\
\text { TSD, which also provides settlement and } \\
\text { custody services to non trading members. }\end{array}$ \\
\hline $\begin{array}{l}\text { 14. CSDs and central counterparties } \\
\text { should have objectives and publicly } \\
\text { disclosed criteria for participation that } \\
\text { permit fair and open access. }\end{array}$ & $\mathrm{O}$ & $\begin{array}{l}\text { The access and exit criteria are clearly } \\
\text { defined and publicly disclosed. TSD accepts } \\
\text { only direct participants located in Thailand. } \\
\text { This is justified by the need to limit the } \\
\text { system's exposure to the risks associated } \\
\text { with cross-border activities. }\end{array}$ \\
\hline
\end{tabular}




\begin{tabular}{|c|c|c|}
\hline Responsibility & Grading & Comments \\
\hline $\begin{array}{l}\text { 15. While maintaining safe and secure } \\
\text { operations, RSSS should be cost-effective } \\
\text { in meeting the requirements of users. }\end{array}$ & $\mathrm{NO}$ & $\begin{array}{l}\text { TSD's settlement and custody fees are } \\
\text { integrated in the aggregated fees collected } \\
\text { by the parent company, SET. These fees } \\
\text { cover trading, clearing, settlement and } \\
\text { custody services. Consequently, TSD is not } \\
\text { able to benchmark its prices against other } \\
\text { CSDs in the region. TSD service levels are } \\
\text { reviewed annually by surveying users. }\end{array}$ \\
\hline $\begin{array}{l}\text { 16. Securities settlement systems should } \\
\text { use or accommodate the relevant } \\
\text { international communication procedures } \\
\text { and standards in order to facilitate } \\
\text { efficient settlement of cross-border } \\
\text { transactions. }\end{array}$ & PO & $\begin{array}{l}\text { TSD uses proprietary communication } \\
\text { network for securities listed on the SET. } \\
\text { This network does not offer a high level of } \\
\text { data transfer protection and the data can be } \\
\text { converted into international standards with } \\
\text { considerable difficulty. For government } \\
\text { bonds, SWIFT message is used. }\end{array}$ \\
\hline $\begin{array}{l}\text { 17. CSDs and central counterparties } \\
\text { should provide market participants with } \\
\text { sufficient information for them to } \\
\text { accurately identify the risks and costs } \\
\text { associated with using the CSD or central } \\
\text { counterparty services. }\end{array}$ & $\mathrm{O}$ & $\begin{array}{l}\text { Laws, regulations, systems' rules, and fees } \\
\text { are part of the contractual agreements that } \\
\text { are to be signed by participants. In } \\
\text { particular, participants' rights, obligations } \\
\text { and costs are defined in these agreements, } \\
\text { which are also available on the TSD website. } \\
\text { TSD has not publicly disclosed the } \\
\text { questionnaire set out in the CPSS/IOSCO } \\
\text { disclosure framework. }\end{array}$ \\
\hline $\begin{array}{l}\text { 18. Securities settlement systems should } \\
\text { be subject to regulation and oversight. } \\
\text { The responsibilities and objectives of the } \\
\text { securities regulator and the central bank } \\
\text { with respect to RSSSs should be clearly } \\
\text { defined, and their roles and major } \\
\text { policies should be publicly disclosed. } \\
\text { They should have the ability and } \\
\text { resources to perform their } \\
\text { responsibilities, including assessing and } \\
\text { promoting implementation of these } \\
\text { recommendations. They should cooperate } \\
\text { with each other and with other relevant } \\
\text { authorities. }\end{array}$ & $\mathrm{PO}$ & $\begin{array}{l}\text { The SEC lacks the legal power to regulate } \\
\text { and supervise TSD. However, through its } \\
\text { regulation of the stock exchange, the SEC } \\
\text { has the possibility to influence the design } \\
\text { and operation of TSD. } \\
\text { TSD is not subject to the oversight } \\
\text { responsibility of the BOT. } \\
\text { The cooperation between the SEC and BOT } \\
\text { is not fully effective. }\end{array}$ \\
\hline $\begin{array}{l}\text { 19. CSDs that establish links to settle } \\
\text { cross-border trades should design and } \\
\text { operate such links to reduce effectively } \\
\text { the risks associated with cross-border } \\
\text { settlement. }\end{array}$ & NA & $\begin{array}{l}\text { TSD has not established links to foreign } \\
\text { CSDs. }\end{array}$ \\
\hline
\end{tabular}




\section{Table 3. Recommended Action Plan to Improve Observance of TSD of the CPSS- IOSCO Recommendations for Securities Settlement Systems}

\begin{tabular}{|c|c|}
\hline Reference Recommendation & Recommended Action \\
\hline Legal risk & $\begin{array}{l}\text { Adequate legal measures should be implemented as soon as } \\
\text { possible to ensure that the netting arrangement is legally protected } \\
\text { even in the event of the insolvency of a participant. }\end{array}$ \\
\hline Pre-settlement risk & $\begin{array}{l}\text { A cost-benefit analysis should be carried out aimed at assessing } \\
\text { whether CCP should be introduced for debt instruments } \\
\text { transactions. } \\
\text { As an immediate measure, the CCP activities should be subject to } \\
\text { the regulation and supervision of the SEC. } \\
\text { SEC is encouraged to assess the CCP function of TSD against the } \\
\text { CPSS/IOSCO Recommendations for CCP. }\end{array}$ \\
\hline Settlement risk & $\begin{array}{l}\text { SEC together with the BOT should explore the possibility to } \\
\text { develop a regulatory framework for dematerialized securities. } \\
\text { TSD should abolish debit balances in securities. } \\
\text { In order to protect the CSD from any contagious risk inherited in } \\
\text { CCP activities, it should consider separating the CCP function } \\
\text { from the CSD function, by setting up a distinct legal entity that } \\
\text { provides CCP services. }\end{array}$ \\
\hline Operational risk & $\begin{array}{l}\text { SEC should receive a copy of the internal and external audit of } \\
\text { TSD policy and procedures to handle operational risk. }\end{array}$ \\
\hline Custody risk & $\begin{array}{l}\text { SEC and BOT should cooperate in order to ensure that custodian } \\
\text { banks are implementing the necessary measures to protect the } \\
\text { customer's assets. } \\
\text { The TSD may consider opening its system to foreign participants }\end{array}$ \\
\hline
\end{tabular}




\begin{tabular}{|c|c|}
\hline Reference Recommendation & Recommended Action \\
\hline Other issues & $\begin{array}{l}\text { The TSD may consider opening its system to foreign participants. } \\
\text { In order to eliminate the risk of cross-subsidizing and increase } \\
\text { transparency, the pricing structure of TSD should be separated } \\
\text { from that of the stock exchange and TSD should have in place } \\
\text { procedures to regularly review its pricing levels against costs of } \\
\text { operation. } \\
\text { The Governance structure of TSD should be strengthened by } \\
\text { appointing more independent board members and by not being } \\
\text { subject to the "regulation power" of the Board of SET. } \\
\text { TSD should enhance its proprietary network to meet international } \\
\text { procedures and standards. } \\
\text { SEC should have the legal power to directly regulate and supervise } \\
\text { TSD without the involvement of the Board of SET. } \\
\text { The BOT should assume its oversight responsibility of TSD and } \\
\text { should set put a dedicated team to oversee the activities of TSD. }\end{array}$ \\
\hline & $\begin{array}{l}\text { The SEC and BOT should develop a cooperation framework that } \\
\text { identifies the responsibility of each authority, aimed at avoiding } \\
\text { overlapping and loopholes. This framework should specify clearly } \\
\text { the tasks of each authority, areas where both authorities have } \\
\text { common interests, exchange of information, etc. For instance and } \\
\text { in line with international experience, the BOT would be } \\
\text { responsible for the containment of systemic risk and the soundness } \\
\text { of clearing and settlement systems, while SEC would be } \\
\text { responsible for the proper conduct, protection of investors, } \\
\text { governance, access and transparency. } \\
\text { In order to increase the effectiveness of their cooperation and } \\
\text { strengthening their overall supervision and oversight roles, the } \\
\text { SEC and the BOT need to increase their mutual understandings of } \\
\text { respective regulatory objectives and needs. } \\
\text { SEC and BOT should enhance the capacity of their staff by setting } \\
\text { up dedicating team in respective authority to deal with securities } \\
\text { clearing and settlement systems. The members of these teams } \\
\text { should be offered specific courses, seminars and on-job training. }\end{array}$ \\
\hline
\end{tabular}

